Journal of Agricultural Sciences
(Tarim Bilimleri Dergisi)

\title{
Foliar Application of Humic Acid and Some Exo-and Endophytic Growth Hormones on Yield, Yield Components and Fatty Acid Composition in Safflower (Carthamus tinctorius L.) under Drought Stress
}

\author{
Mojgan HEYDARI ${ }^{a} \mathbb{D}$, Hamid Reza TOHIDI MOGHADAM ${ }^{\mathrm{a}^{*}} \mathbb{D}^{\mathbb{D}}$, Farshad GHOOSHCHI $^{\mathrm{a}} \mathbb{D}^{\mathbb{D}}$, Seyed Ali Mohammad \\ MODARRES-SANAVYb ${ }^{\mathbb{D}}$, Pourang KASRAIE ${ }^{\mathrm{a}}$ iD \\ ${ }^{a}$ Department of Agriculture, Varamin-Pishva Branch, Islamic Azad University, Varamin, IRAN \\ ${ }^{b}$ Department of Agronomy, Tarbiat Modares University, Tehran, IRAN
}

\section{ARTICLE INFO}

Research Article

Corresponding Author: Hamid Reza TOHIDI MOGHADAM, E-mail: tohidi_moghadam@yahoo.com

Received: 04 June 2020 / Revised: 24 July 2020 / Accepted: 04 August 2020 / Online: 04 December 2021

\section{ABSTRACT}

A two-year field experiment was conducted in Varamin-Pishva Branch, Islamic Azad University, Iran to study the impact of drought stress and foliar application of some hormones on the safflower growth. The drought stress was induced at three levels and considered as main plots. Irrigating after $75 \%$ water depletion was considered to be normal irrigation (control), irrigating after 60 and $45 \%$ water depletion, defined as mild and severe drought stress, respectively. The foliar application of humic acid (HA), salicylic acid (SA), Gibberellic acid $\left(\mathrm{GA}_{3}\right)$, ascorbic acid (AA), water, and the non-foliar application was considered as sub-plots. The main effect of irrigation regimes was significant on seed yield, oil yield, palmitic acid, and water use efficiency (WUE). Also, the main effect of foliar applications was significant for seed yield, oil yield, stearic acid, and WUE. Normal irrigation produced the maximum oil yield $(2270 \mathrm{~kg}$ $\mathrm{ha}^{-1}$ ) that was decreased by $25.9 \%$ and $37.1 \%$ under mild and severe stress regimes, respectively. The maximum and minimum oil yields were produced by the application of SA and non-foliar treatment with average values 1970 and $1357 \mathrm{~kg} \mathrm{ha}^{-1}$, respectively. Although the palmitic acid content was enhanced under the drought stress conditions, oleic acid content was significantly decreased in such conditions. The current findings suggest that the foliar application of SA can be recommended when optimal water supply was applied to increase the quality and quantity of safflower oilseed.

Keywords: Ascorbic acid, Foliar spray, Gibberellic acid, Safflower (Carthamus tinctorius L.), Salicylic acid

(C) Ankara University, Faculty of Agriculture

\section{Introduction}

The Safflower (Carthamus tinctorius L.) is one of the oldest oilseed crops, which is native to the Middle East (Mohammadi et al. 2019), and it is usually grown for flowers, medicinal products, cooking and coloring purposes (Çamaş \& Esendal 2006). Environmental factors and different types of stress conditions affect growth parameters, herbage yield, and essential oil composition of medicinal and aromatic plants. The scarcity of water has a direct effect on plant biomass, affecting also physiological and morphological traits, including canopy architecture and plant antioxidant system (Keshavarz \& Khodabin 2019; Chavoushi et al. 2020). Decreases in chlorophyll content, yield and yield components were observed for the safflower under drought stress conditions (Mona et al. 2012). Drought stress severely affected safflower productivity and biological yield compared to normal watering. Plant hormones can play vital roles in plant growth and development processes response to various abiotic and biotic stress (Shaki et al. 2019). Plant hormones have been used to improve the growth and development of different crop species (Keshavarz et al. 2016; Dotto \& Neumann Silva 2017; Shaki et al. 2020). The Gibberellic acid (GA 3 ) plays essential roles in seed germination, stem elongation, leaf expansion and reproductive development (Khan \& Chaudhry 2006). Baydar (2002) reported that the oil synthesis of safflower increased significantly from $33.8 \%$ to $38.8 \%$ with the application of 300 ppm $\mathrm{GA}_{3}$ at the budding stage. In another study, Bibi et al. (2003) indicated that increasing concentrations of GA $\mathrm{G}_{3}$ gradually improved the oil content of sunflower. The salicylic acid (SA) is a natural substance that can induce stem elongation, leaf epinasty and yield increase (Keshavarz et al. 2016). The ability of exogenous SA to enhance antioxidant protection, to increase the accumulation of osmolytes, and to maintain optimum chlorophyll pigments under stress conditions has been suggested as potential mechanisms of drought tolerance in safflower (Ghassemi-Golezani et al. 2020). SA regulates various aspects of plant responses to stress through extensive signaling cross-talk with other hormones such as $\mathrm{GA}_{3}$ and indol-3-acetic acid (Jayakannan et al. 2013). Several studies have found that treatment with SA improved the tolerance of safflower to drought stress (Chavoushi et al. 2019, Chavoushi et al. 2020). Shaki et al. (2019) found that SA improved the biomass production and fatty acid composition of the safflower in drought conditions. The application of (humic acid) HA is a practice that can improve water use efficiency (WUE) and decrease the effect of drought stress on plants (Zhang et al. 2013). Tohidi Moghadam et al. (2014) and Yadollahi et 
al. (2015) demonstrated a significant increase in the safflower and corn (Zea mays L.) yield by applying HA under drought conditions. Similarly, Khademian et al. (2019) found that the application of humic acid improved plant photosynthesis in drought conditions via increasing the rate of gas exchange and electron transport flux in safflower (Carthamus tinctorius L.). This study aims to compare the drought stress and foliar application of some exo-and endophytic growth hormones on leaf area index (LAI), water use efficiency and seed quality and quantity of safflower.

\section{Material and Methods}

This experiment was conducted in the research field of Agriculture Faculty of Tarbiat Modares University, Tehran, Iran during two cropping seasons (in 2017-2018 and 2018-2019) to investigate the effect of foliar application of HA, SA, GA 3 and ascorbic acid (AA) on quantitative and qualitative characteristics of the safflower under drought stress conditions. Weather conditions such as temperature and precipitation were obtained from Chitgar (51 $10^{\circ} \mathrm{E}, 33^{\prime} 44^{\prime} \mathrm{N}, 1305.2 \mathrm{~m}$ asl) weather station which is 1 $\mathrm{km}$ from field condition. The average annual temperature is $14.2^{\circ} \mathrm{C}$ and the average annual rainfall is $244 \mathrm{~mm}$ in Karaj. The soil of the experimental site was classified as clay loamy soil, organic matter of 1.28 and $\mathrm{pH}$ was 7.8 . Available soil nitrogen and phosphorus at depth of $60 \mathrm{~cm}$ were $14.9 \mathrm{ppm}$ and $41.8 \mathrm{ppm}$, respectively. The experiments were designed with a split-plot design in a randomized complete block design. The safflower (Carthamus tinctorius L.) seeds registered and provided by the National Seed and Plant Improvement Institute, Iran, Karaj. Each experiment included fifty-four experimental units including, three irrigation treatment and six foliar applications with three replications. A drip irrigation system was used to watered all treatments to ensure uniform seed germination. Irrigation regimes (drought stress) were started early spring (April $4^{\text {th }}$, both year, flowering stage) and continued throughout the season (ending mid-July, both year). The plots were irrigated at $75 \%$ of field capacity (no stress), $60 \%$ of field capacity (mild stress) and $45 \%$ of field capacity (severe stress). Irrigation water $\left(\mathrm{V}_{\mathrm{w}}\right.$ in $\left.\mathrm{m}^{3}\right)$ was estimated based soil moisture at field capacity using by TDR method (Time Domain Reflectometry method, model 4593, soil moisture equipment, Santa Barbara), according to the following equation (1):

$\mathrm{V}_{\mathrm{w}}:\left(\theta_{\mathrm{F} . \mathrm{C}}-\theta_{\mathrm{i}}\right) \times \mathrm{D} \times \mathrm{A}$

(Equation 1)

Where, $\theta_{F . C}$ is the volume of soil moisture at field capacity, $A$ is the main plot area $\left(\mathrm{m}^{2}\right)$ and $D$ is the root depth. Soil moisture was monitored throughout the whole growth period by taking soil samples at the depth of $60 \mathrm{~cm}$, with a neutron probe (twice weekly). The amounts of water to plots were controlled by contour. WUE was calculated by dividing the marketable yields by the volume of applied water.

The foliar application $\left[\left(\mathrm{F}_{1}\right.\right.$ : HA $300 \mathrm{mg} \mathrm{L}^{-1}, \mathrm{~F}_{2}$ : SA $100 \mathrm{mg} \mathrm{L}^{-1}, \mathrm{~F}_{3}: \mathrm{GA}_{3} 50 \mathrm{mg} \mathrm{L}^{-1}, \mathrm{~F}_{4}$ : AA $150 \mathrm{mg} \mathrm{L}^{-1}$, $\mathrm{F}_{5}$ : Water and $\mathrm{F}_{6}$ : non-foliar application)] was considered as a sub-factor and were applied at rosette stage (Lewis \& McFarlane 1986) with a pressurized backpack sprayer (12 L capacity) calibrated to deliver $1000 \mathrm{~L} \mathrm{ha}^{-1}$ of spray solution. The experimental field was prepared by shallow plowing, followed by disking in September and October of each year (2017 and 2018). Each experimental plot had six rows $(6 \mathrm{~m})$ and $5 \mathrm{~cm}$ spacing between plants in rows with $50 \mathrm{~cm}$ distanced. In both years seeds were cultivated by hand on the $20^{\text {th }}$ and $25^{\text {th }}$ of November. After seed sowing, irrigation water was reapplied when $25 \%$ of the available soil water was used until the plants were established. The amounts of urea ( $350 \mathrm{~kg} \mathrm{ha}^{-1}$ urea) were applied (based on local recommended) at three different stages; one-third before seed sowing and mixed into the soil, one-third at stem elongation stage and one-third at capitulum emergence stages stage by spreading the fertilizer onto the soil surface just before irrigation. All operations related to the harvesting except irrigation were carried out uniformly and according to the traditions of the area.

At the first of the Capitulum forming stage, three representative plants per plot were chosen for the leaf area index (using a leaf area meter, Delta-T Devices Ltd., Cambridge, UK). In both years the final harvest was performed on August $16^{\text {th }}$ at the physiological maturity stage. To determine morphologically and 1000 seed weight, 10 plants from each plot and to measure seed yield, $2 \mathrm{~m}^{2}$ of each plot from the middle of each plot were hand-harvested at the physiological maturity stage.

The percentage of seed oil and gas chromatography analysis was done according to the method described by AzadmardDamirchi et al. (2005). Oil percentage was measured by Inframatic 8620 Percor, England. Oil yield was obtained by multiplying seed yield by oil percentage. The oil sample for each treatment was converted to methyl esters in the presence of $\mathrm{Menthol} \mathrm{BF}_{3}{ }^{-1}$ $(14 \% \mathrm{w} / \mathrm{w})$ reagent and using sodium methoxide as a catalyst. Samples of $200 \mathrm{mg}$ oil were added to 7 ml sodium methylate $(0.5$ M) and heated to boiling for $10 \mathrm{~min}$. After that $5 \mathrm{ml}$ Boron Trifluoride in menthol was added to the mixture, heated again for 2 min and $6 \mathrm{ml} \mathrm{n}$-hexane (GC grade) added to complex and heated for $2 \mathrm{~min}$. In the end, $50 \mathrm{ml}$ saturated saline water added and suspension strongly shaken for $1 \mathrm{~min}$. The upper phase $(0.5 \mu \mathrm{L})$ was taken and analyzed by GC (GC 8000, Carlo-Erba Instruments, Italy) equipped with the flame ionization detector (FID) on a DB23 fused silica capillary column ( $30 \mathrm{~m}$ by $0.25 \mathrm{~mm}$ i.d., $\mathrm{d}_{\mathrm{r}}=0.25 \mu \mathrm{m}$ film; J and W Scientific, Folsom, CA). Nitrogen was utilized as carrier gas at a flow rate of $4.93 \mathrm{~mL} \mathrm{~min}{ }^{-1}$ and the split ratio was $21.28 \mathrm{~mL} \mathrm{~min}^{-1}$. The $\mathrm{GC}$ process was conducted as split mode injection at an oven temperature of $120^{\circ} \mathrm{C}$ for

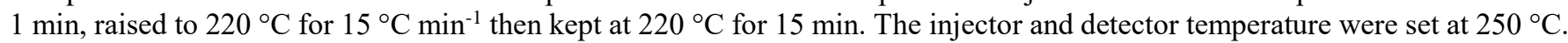
Peak identification was performed by comparing with the retention time of valid commercial standards (Sigma Co., USA). The fatty acid content of stearic acid, oleic acid, palmitic acid, and linolenic acid was shown as a percentage of the oil. 
The main and interaction effects of experimental factors were determined from analysis of variance (ANOVA) in SAS (SAS Institute Inc. 2002). The significance of differences among treatment means was tested using LSD at a probability level of $1 \%$ and $5 \%$ and the significant interaction effects were separated by the slicing method.

\section{Results}

Significance for irrigation regimes, foliar application treatments, two-way interactions, and three-way interactions for the studied traits are presented in Table 1. The main effect of year was not statistically significant on all studied traits except for the LAI $(\mathrm{P}<0.01)$, which might be due to the same mean temperature in both years (Figure 1). The results of the combined analysis of variance showed that the irrigation regimes differed significantly in terms of seed yield, oil yield, palmitic acid, and WUE (Table 1). Also, foliar application treatments differed significantly for seed yield, oil yield, stearic acid, and WUE (Table 1). The twoway interaction of irrigation regimes $\times$ foliar application treatments was significant for oleic acid $(\mathrm{P} \leq 0.01)$.

Table 1- Combined analysis of variance on agronomic and some physiological traits of the safflower as affected by foliar application treatments and irrigation regimes

\begin{tabular}{|c|c|c|c|c|c|c|}
\hline S.O.V & D.F & $L A I$ & $\begin{array}{c}\text { 1000-seed } \\
\text { weight } \\
(\mathrm{g}) \\
\end{array}$ & $\begin{array}{l}\text { Seed yield } \\
\quad\left(k g h^{-1}\right)\end{array}$ & $\begin{array}{c}\text { Oil yield } \\
\left(k g h^{-1}\right)\end{array}$ & $\begin{array}{l}\text { Oil content } \\
\quad(\%)\end{array}$ \\
\hline Year (Y) & 1 & $0.35^{*}$ & $22.18^{\text {ns }}$ & $25223.0^{\mathrm{ns}}$ & $3956.5^{\mathrm{ns}}$ & $1.12^{\mathrm{ns}}$ \\
\hline Y (Block) & 4 & 0.02 & 6.10 & 12483841.3 & 1763257.5 & 5.51 \\
\hline Drought stress (S) & 2 & $2.51^{* *}$ & $15.19^{\text {na }}$ & $62172702.5^{* *}$ & $7122808.9^{* *}$ & $14.09^{\mathrm{ns}}$ \\
\hline $\mathrm{Y} \times \mathrm{S}$ & 2 & $0.21^{*}$ & $1.74^{\mathrm{na}}$ & $42397.8^{\mathrm{ns}}$ & $1919.8^{\mathrm{ns}}$ & $0.64^{\mathrm{ns}}$ \\
\hline Block $(\mathrm{Y} \times \mathrm{S})$ & 8 & 0.02 & 6.48 & 1234367.5 & 179032.3 & 5.57 \\
\hline Foliar application (FA) & 5 & $0.09^{\mathrm{ns}}$ & $32.96^{* *}$ & $8408850.5^{* *}$ & $957661.5^{* *}$ & $6.76^{\mathrm{ns}}$ \\
\hline $\mathrm{Y} \times \mathrm{FA}$ & 5 & $0.01^{\mathrm{ns}}$ & $6.83^{\text {na }}$ & $2310162.7^{\mathrm{ns}}$ & $195590.7^{\mathrm{ns}}$ & $39.76^{* *}$ \\
\hline $\mathrm{S} \times \mathrm{FA}$ & 10 & $0.03^{\mathrm{ns}}$ & $2.31^{\mathrm{na}}$ & $820422.5^{\mathrm{ns}}$ & $86084.4^{\mathrm{ns}}$ & $14.61^{* *}$ \\
\hline $\mathrm{Y} \times \mathrm{S} \times \mathrm{FA}$ & 10 & $0.09^{*}$ & $5.30^{\mathrm{na}}$ & $292093.6^{\mathrm{ns}}$ & $93744.8^{\mathrm{ns}}$ & $13.41^{* * *}$ \\
\hline Error & 60 & 0.04 & 5.24 & 1345210.3 & 171839.9 & 4.68 \\
\hline $\mathrm{CV}(\%)$ & & 18.27 & 6.72 & 23.32 & 23.46 & 6.06 \\
\hline S.O.V & D.F & $\begin{array}{c}\text { Palmitic acid } \\
(\%)\end{array}$ & $\begin{array}{c}\text { Stearic acid } \\
(\%)\end{array}$ & $\begin{array}{c}\text { Oleic acid } \\
(\%)\end{array}$ & $\begin{array}{c}\text { Linoleic acid } \\
(\%)\end{array}$ & $\begin{array}{c}\text { WUE } \\
\left(\mathrm{kg} \mathrm{ha}^{-1} \mathrm{~mm}^{-1}\right)\end{array}$ \\
\hline Year $(\mathrm{Y})$ & 1 & $0.168^{\mathrm{ns}}$ & $0.013^{\text {ns }}$ & $0.19^{\text {ns }}$ & $0.002^{\mathrm{ns}}$ & $0.001^{\mathrm{ns}}$ \\
\hline Y (Block) & 4 & 0.047 & 0.276 & 27.74 & 3.66 & 0.599 \\
\hline Drought stress (S) & 2 & $0.615^{* *}$ & $0.167^{\mathrm{ns}}$ & $480.04^{* *}$ & $5.33^{\mathrm{ns}}$ & $0.198^{*}$ \\
\hline $\mathrm{Y} \times \mathrm{S}$ & 2 & $0.005^{\mathrm{ns}}$ & $0.009^{\mathrm{ns}}$ & $0.25^{\mathrm{ns}}$ & $2.11^{\mathrm{ns}}$ & $0.003^{\text {ns }}$ \\
\hline $\operatorname{Block}(\mathrm{Y} \times \mathrm{S})$ & 8 & 0.041 & 0.102 & 34.33 & 1.95 & 0.027 \\
\hline Foliar application (FA) & 5 & $0.018^{\mathrm{ns}}$ & $0.164^{*}$ & $13.92^{* *}$ & $3.34^{\mathrm{ns}}$ & $0.437^{* *}$ \\
\hline $\mathrm{Y} \times \mathrm{FA}$ & 5 & $0.007^{\mathrm{ns}}$ & $0.082^{\text {ns }}$ & $1.39^{\mathrm{ns}}$ & $1.99^{\mathrm{ns}}$ & $0.130^{\text {ns }}$ \\
\hline $\mathrm{S} \times \mathrm{FA}$ & 10 & $0.051^{\mathrm{ns}}$ & $0.085^{\mathrm{ns}}$ & $9.35^{* *}$ & $1.16^{\mathrm{ns}}$ & $0.0355^{\mathrm{ns}}$ \\
\hline $\mathrm{Y} \times \mathrm{S} \times \mathrm{FA}$ & 10 & $0.034^{\mathrm{ns}}$ & $0.043^{\text {ns }}$ & $0.80^{\mathrm{ns}}$ & $0.57^{\mathrm{ns}}$ & $0.0166^{\mathrm{ns}}$ \\
\hline Error & 60 & 0.035 & 0.050 & 3.52 & 1.54 & 0.069 \\
\hline $\mathrm{CV}(\%)$ & & 2.99 & 8.10 & 11.37 & 1.63 & 23.27 \\
\hline
\end{tabular}

S.O.V.: the Source Of Variation; D.F: the Degree of Freedom; LAI: Leaf Area Index; WUE: Water Use Efficiency; CV: Coefficient of Variance; ns: not significant; * and $* *$ Significant at the $5 \%$ and $1 \%$ levels of probability, respectively 


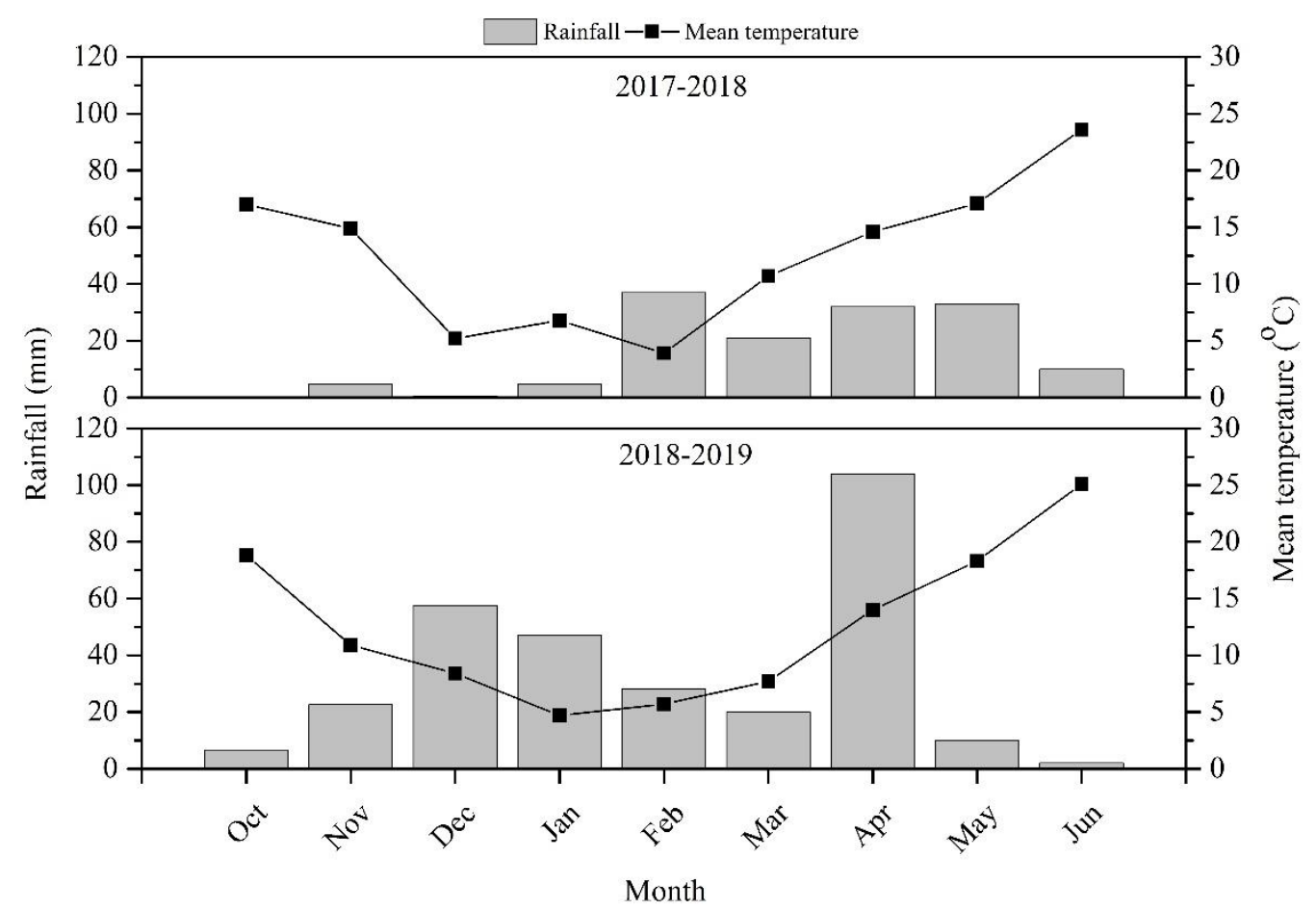

Figure 1- Rainfall and mean temperatures during the growing season

\subsection{Agronomic traits}

The LAI responded differently to irrigation regimes and the foliar application treatments each year, so means are presented separately for each year (Table 2). Averaged over foliar application treatments in the first year, the LAI decreased by $21.5 \%$ and $52.4 \%$ under mild and severe stress, respectively, compared with the well-watered regime (Table 2). In the second year, the nostress regime produced the highest the LAI, with an average 2.53 that was reduced by $43.1 \%$ and $66.3 \%$ under the mild and severe stress regimes, respectively (Table 2).

Table 2- Three-way interaction year $\times$ irrigation regime $\times$ foliar application on LAI and oil content

\begin{tabular}{|c|c|c|c|c|c|c|c|}
\hline \multirow[b]{2}{*}{ Year } & \multirow[b]{2}{*}{ Treatment } & \multicolumn{3}{|c|}{$L A I$} & \multicolumn{3}{|c|}{ Oil content (\%) } \\
\hline & & No stress & Mild stress & Severe stress & No stress & Mild stress & Severe stress \\
\hline \multirow{5}{*}{ First } & HA & $1.07 \mathrm{a}$ & $1.80 \mathrm{a}$ & $1.08 \mathrm{a}$ & $34.46 \mathrm{~b}$ & $36.95 \mathrm{ab}$ & $39.93 \mathrm{a}$ \\
\hline & SA & $1.71 \mathrm{a}$ & $1.66 \mathrm{a}$ & $0.95 \mathrm{a}$ & $34.03 \mathrm{~b}$ & $34.18 \mathrm{bc}$ & $34.64 \mathrm{c}$ \\
\hline & $\mathrm{GA}_{3}$ & $2.64 \mathrm{a}$ & $1.17 \mathrm{a}$ & $0.89 \mathrm{a}$ & $35.53 \mathrm{ab}$ & $35.36 \mathrm{abc}$ & $34.46 \mathrm{c}$ \\
\hline & AA & $1.96 \mathrm{a}$ & $1.25 \mathrm{a}$ & $0.83 \mathrm{a}$ & $37.40 \mathrm{a}$ & $38.67 \mathrm{a}$ & $36.15 \mathrm{bc}$ \\
\hline & Water & $1.61 \mathrm{a}$ & $1.23 \mathrm{a}$ & $0.76 \mathrm{a}$ & $35.40 \mathrm{ab}$ & $34.66 \mathrm{bc}$ & $38.38 \mathrm{ab}$ \\
\hline \multirow{7}{*}{ Second } & No treatment & $1.60 \mathrm{a}$ & $1.20 \mathrm{a}$ & $0.53 \mathrm{a}$ & $33.31 \mathrm{~b}$ & $32.58 \mathrm{c}$ & $34.59 \mathrm{c}$ \\
\hline & HA & $3.13 \mathrm{a}$ & $1.65 \mathrm{ab}$ & $0.53 \mathrm{~b}$ & $35.67 \mathrm{abc}$ & $37.43 \mathrm{ab}$ & $34.28 \mathrm{a}$ \\
\hline & SA & $3.01 \mathrm{a}$ & $1.28 \mathrm{abc}$ & $1.10 \mathrm{a}$ & $36.74 \mathrm{ab}$ & $30.86 \mathrm{c}$ & $38.76 \mathrm{a}$ \\
\hline & $\mathrm{GA}_{3}$ & $2.90 \mathrm{a}$ & $1.71 \mathrm{a}$ & $0.78 \mathrm{ab}$ & $36.86 \mathrm{ab}$ & $33.67 \mathrm{bc}$ & $35.88 \mathrm{a}$ \\
\hline & AA & $1.82 \mathrm{~b}$ & $1.22 \mathrm{bc}$ & $0.91 \mathrm{a}$ & $31.84 \mathrm{c}$ & $36.81 \mathrm{ab}$ & $34.79 \mathrm{a}$ \\
\hline & Water & $2.76 \mathrm{a}$ & $1.61 \mathrm{abc}$ & $0.83 \mathrm{a}$ & $32.22 \mathrm{bc}$ & $34.05 \mathrm{bc}$ & $37.56 \mathrm{a}$ \\
\hline & No treatment & $1.60 \mathrm{~b}$ & $1.17 \mathrm{c}$ & $0.97 \mathrm{a}$ & $39.85 \mathrm{a}$ & $39.57 \mathrm{a}$ & $37.56 \mathrm{a}$ \\
\hline
\end{tabular}


Although in the first year, there was no significant difference between the foliar application treatments in each irrigation regime (control, mild and severe stress) in terms of the LAI, a statistically significant difference was observed among foliar application treatments in the three irrigation regimes in the second year (Table 2). The HA, the GA 3 , and the SA treatments showed the highest LAI, with average values 3.13, 1.71, and 1.10 under the control, mild and severe stress regimes, respectively (Table 2). The 1000-seed weight showed a various response under foliar application treatments, ranging from $35.12 \mathrm{~g}$ for the $\mathrm{GA}_{3}$ treatment to $31.63 \mathrm{~g}$ for the non-foliar treatment (Table 3). The maximum seed yield was observed in the no stress regime, with an average $6449.1 \mathrm{~kg} \mathrm{ha}^{-1}$ that was reduced by $29.6 \%$ and $39.1 \%$ under mild and severe stress, respectively (Table 4). The seed yield was significantly affected by the foliar application treatments so that the SA and non-foliar treatments, with average values 5634.8 and $3757.1 \mathrm{~kg} \mathrm{ha}^{-1}$, respectively (Table 3), produced the maximum and minimum seed yields.

Table 3- Main effect of foliar application treatments on different traits of safflower

\begin{tabular}{|c|c|c|c|c|c|}
\hline Treatment & $\begin{array}{c}1000 \text {-seed weight } \\
(\mathrm{g})\end{array}$ & $\begin{array}{l}\text { Seed yield } \\
\quad\left(k g h^{-1}\right)\end{array}$ & $\begin{array}{l}\text { Oil yield } \\
\left(k g h^{-1}\right)\end{array}$ & $\begin{array}{l}\text { Stearic acid } \\
(\%)\end{array}$ & $\begin{array}{c}\text { WUE } \\
\left(\mathrm{kg} \mathrm{ha}^{-1} \mathrm{~mm}^{-1}\right)\end{array}$ \\
\hline HA & $34.74 \mathrm{ab}$ & $4817.5 \mathrm{~b}$ & $1746.6 \mathrm{ab}$ & $2.95 \mathrm{a}$ & $1.08 \mathrm{~b}$ \\
\hline SA & $35.12 \mathrm{a}$ & $5634.8 \mathrm{a}$ & $1970.6 \mathrm{a}$ & $2.79 \mathrm{~b}$ & $1.29 \mathrm{a}$ \\
\hline $\mathrm{GA}_{3}$ & $34.83 \mathrm{a}$ & $5337.1 \mathrm{ab}$ & $1886.9 \mathrm{ab}$ & $2.68 \mathrm{~b}$ & $1.21 \mathrm{ab}$ \\
\hline AA & $34.72 \mathrm{ab}$ & $5446.3 \mathrm{ab}$ & $1954.7 \mathrm{ab}$ & $2.77 \mathrm{~b}$ & $1.23 \mathrm{ab}$ \\
\hline Water & $33.25 \mathrm{~b}$ & $4827.5 \mathrm{~b}$ & $1684.6 \mathrm{~b}$ & $2.76 \mathrm{~b}$ & $1.07 \mathrm{~b}$ \\
\hline No treatment & $31.63 \mathrm{c}$ & $3757.1 \mathrm{c}$ & $1357.4 \mathrm{c}$ & $2.70 \mathrm{~b}$ & $0.86 \mathrm{c}$ \\
\hline
\end{tabular}

HA: Humic Acid; SA: Salicylic Acid; GA are not significantly different at $5 \%$ probability level by Least Significant Difference test.

\subsection{Oil content and its yield level}

There were significant differences in oil yield of the safflower at the different irrigation regimes (Table 1), so that the control treatment produced the maximum oil yield, with an average $2270.57 \mathrm{~kg} \mathrm{ha}^{-1}$ that was decreased by $25.9 \%$ and $37.1 \%$ under mild and severe stress, respectively (Table 4). The foliar application treatments had a significant effect on the oil yield of safflower (Table 1). The highest oil yield was observed in the SA treatment with an average $1970.6 \mathrm{~kg} \mathrm{ha}^{-1}$ that was $11.36 \%, 4.24 \%, 0.80 \%$, $14.51 \%$, and $31.11 \%$ higher than the $\mathrm{SA}$, the $\mathrm{GA}_{3}$, the $\mathrm{AA}$, water, and non-foliar treatments, respectively (Table 3). In terms of oil content, averaged across foliar application treatments in the first year, the no-stress regime had the lowest oil content (35.02\%) which was increased by $1.1 \%$ and $2.7 \%$ under the mild and severe stress regimes, respectively (Table 2). Averaged by the foliar application treatments in the second year, the oil content of control, mild and severe stress regimes were $35.53 \%, 35.39 \%$, and $36.74 \%$, respectively (Table 2).

The oil content of safflower responded differently to irrigation regimes and the foliar application treatments in each year (Table 2). In the first year, the oil content varied from $37.40 \%$ for the AA treatment to $33.31 \%$ for the non-foliar treatment in the optimal water supply (control), from $38.67 \%$ for the AA treatment to $32.58 \%$ for the non-foliar treatment in mild drought stress, and from $39.93 \%$ for the HA treatment to $34.46 \%$ for the $\mathrm{GA}_{3}$ treatment (Table 2). In 2017-2018 (first year), the control treatment (the non-foliar application) had the maximum oil content with an average $39.85 \%, 39.57 \%$, and $37.56 \%$ in the control, mild and severe regimes, respectively (Table 2).

Table 4- Main effect of irrigation regimes on different traits of safflower

\begin{tabular}{lcccc}
\hline Drought Treatment & $\begin{array}{c}\text { Seed yield } \\
\left(\text { Kg ha }^{-1}\right)\end{array}$ & $\begin{array}{c}\text { Oil yield } \\
\left(\text { Kg ha }^{-1}\right)\end{array}$ & $\begin{array}{c}\text { Palmitic acid } \\
(\%)\end{array}$ & $\begin{array}{c}\text { WUE } \\
\left(\mathrm{kg} \mathrm{ha}^{-1} \mathrm{~mm}^{-1}\right)\end{array}$ \\
\hline No stress & $6449.1 \mathrm{a}$ & $2270.57 \mathrm{a}$ & $6.16 \mathrm{~b}$ & $1.13 \mathrm{ab}$ \\
Mild stress & $4540.1 \mathrm{~b}$ & $1601.55 \mathrm{~b}$ & $6.23 \mathrm{~b}$ & $1.05 \mathrm{~b}$ \\
Severe stress & $3930.0 \mathrm{c}$ & $1428.24 \mathrm{~b}$ & $6.41 \mathrm{a}$ & $1.20 \mathrm{a}$ \\
\hline
\end{tabular}

WUE: Water Use Efficiency; Means followed by similar letters in columns are not significantly different at $5 \%$ probability level by Least Significant Difference test 


\subsection{Fatty acid composition}

Although the linoleic acid was not affected by the irrigation regimes and foliar application treatments, the palmitic, stearic, and oleic acids showed a different response to these treatments (Table 1). When compared with the control irrigation (no stress), mild and severe stress increased palmitic acid by $1.13 \%$ and $4.05 \%$, respectively, while the oleic acid content was reduced by $30.64 \%$ and $30.41 \%$ (averaged over the foliar application treatments) compared with the well-watered regime (Table 4).

The maximum stearic acid content belonged to the HA treatment with an average of $2.95 \%$ that was $5.42 \%, 9.15 \%, 6.10 \%$, $6.44 \%$, and $8.47 \%$ higher than the $\mathrm{SA}$, the $\mathrm{GA}_{3}$, the AA, the water, and non-foliar, respectively (Table 3). The oleic acid content responded differently to irrigation regimes and the foliar application treatments (Table 5). The AA treatments had the maximum oleic acid content with average values of $23.12 \%, 15.27 \%$, and $15.19 \%$ under control, mild, and severe stress, respectively (Table 5). It is worth noting that there was no significant difference among the foliar application treatments under the severe stress condition in terms of the oleic acid content. Moreover, foliar application treatments did not show any significant difference in terms of the linoleic acid content.

\subsection{Water Use Efficiency (WUE)}

The average WUE was different in the three drought stress irrigation regimes (Table 4). The maximum WUE was observed when the severe drought stress regime imposed during the growing season with an average $1.20 \mathrm{~kg} \mathrm{ha}^{-1} \mathrm{~mm}^{-1}$, while the mild stress showed the minimum amount of WUE with an average $1.05 \mathrm{~kg} \mathrm{ha}^{-1} \mathrm{~mm}^{-1}$ (Table 4). A significant difference was observed among the foliar application treatments in terms of the WUE (Table 3). The foliar application of SA showed the maximum WUE with an average $1.29 \mathrm{~kg} \mathrm{ha}^{-1} \mathrm{~mm}^{-1}$ that was $16.27 \%, 6.20 \%, 4.65 \%, 17.05 \%$, and $33.33 \%$ higher than the WUE with foliar application of the HA, the $\mathrm{GA}_{3}$, AA, water, and non-foliar treatment, respectively (Table 3).

Table 5- Interaction between irrigation regime and foliar application on oleic acid

\begin{tabular}{llcl}
\hline \multicolumn{3}{c}{ Oleic acid $(\%)$} & Severe stress \\
\hline Treatment & No stress & Mild stress & $14.23 \mathrm{a}$ \\
$\mathrm{HA}$ & $19.42 \mathrm{ab}$ & $15.27 \mathrm{a}$ & $14.35 \mathrm{a}$ \\
$\mathrm{GA}_{3}$ & $22.93 \mathrm{a}$ & $13.77 \mathrm{~b}$ & $14.08 \mathrm{a}$ \\
$\mathrm{AA}$ & $20.72 \mathrm{ab}$ & $14.02 \mathrm{ab}$ & $15.19 \mathrm{a}$ \\
Water & $23.12 \mathrm{a}$ & $15.26 \mathrm{a}$ & $14.35 \mathrm{a}$ \\
No treatment & $20.84 \mathrm{ab}$ & $13.90 \mathrm{ab}$ & $14.32 \mathrm{a}$ \\
\hline
\end{tabular}

HA: Humic Acid, SA: Salicylic Acid; GA 3 : Gibberellic Acid; AA: Ascorbic Acid; Means followed by similar letters in columns are not significantly different at $5 \%$ probability level by Least Significant Difference test.

\section{Discussion}

Drought stress inhibits plant growth and productivity via limiting photosynthesis. Change in photosystem I and II activities can cause some modifications in the thylakoid membrane proteins, leading to a decline in electron transfer from the light-harvesting antenna to photosystem II which eventually may lead to photo-inhibitory destruction of photosystem II reaction centers (Ghassemi-Golezani et al. 2020). The results of this research indicated that the safflower LAI decreased when plants experienced drought stress conditions. Indeed, the reduction in LAI under drought stress is a typical symptom of oxidative stress (Mohammadi et al. 2018). Reduction in the LAI under drought stress led to the loss of plant biomass because of lower photosynthesis rates (Shaki et al. 2109). The plants usually decrease leaf areas to minimize water loss by transpiration under drought stress conditions (Keshavarz et al. 2018). The results in the current study are in agreement with Chavoushi et al. (2019) who found that the LAI was significantly reduced when water stress was imposed over the growing period. The drought stress irrigation regimes affected seed yield safflower. The number of seeds per capitulum, the 1000-seed weight, and the LAI decreased under drought stress, leading to a reduction in seed yield (Golparvar 2011). Some authors have reported a decrease in seed yield for safflower (SoheiliMovahhed et al. 2019; Chavoushi et al. 2020). The 1000-seed weight was different among the foliar application treatments and was enhanced by the application of the plant growth regulators. Foliar application of humic acid or salicylic acid increased 1000seed weight, seed yield and oil yield safflower. Increasing these traits by application of plant hormones could be resulted from the rising photosystem II activity due to conformational modifications in some proteins (Ghassemi-Golezani et al. 2020), affecting changes in the properties of photosystem II electron acceptors. In addition, the increasing grain weight might be attributed to an increase in the period or rate of grain filling period (Mohtashami et al. 2016). The decreased in seed weight under 
drought stress has been indicated in safflower (Movahhedy-Dehnavy et al. 2009) Also, the stress resistance increases through mechanisms of metabolic defence under the foliar application of the plant growth regulators, leading to better plant growth and seed yield (Ullah et al. 2012, Keshavarz \& Sadegh Ghol Moghadam 2017). The earlier study confirmed that foliar application of safflower with some nutritions effectively prevented the plant from oxidative stress (Janmohammadi et al. 2016). In a previous study, Moradi et al. (2017) concluded that the seed yield of safflower increased by $6.02 \%$ when fulvic acid was added by the foliar application.

Although genotype is considered the most important factor to determine the oil content, the drought stress may affect the seed oil content (Amini et al. 2014). As previously explained, water stress conditions affected plant growth and development, leading to an effect on seed oil composition. The optimal water supply over the growing period could enhance oil content in safflower, while drought stress reduces it (Soheili-Movahhed et al. 2019). A reduction in oil content might be attributed to the oxidation of polyunsaturated fatty acids (Golparvar 2011). The reduction in oil content when drought stress occurred during the growing season is supported by some reports (Mona et al. 2012). The plant growth regulators can improve seed oil content due to their positive effect in seed during biosynthesis and storage of fatty acid and oil over the seed filling stage (Ali et al. 2013). Golkar et al. (2019) showed that salicylic acid enhances safflower tolerance to drought stress by increasing the antioxidative activities. Antioxidative activities have an important role in alleviating drought oxidative stress in plants (Chavoushi et al. 2020). Exogenous SA can protect photosynthetic pigments from oxidative damage that may help to maintain normal photosynthesis of safflower. The reduction of oil content under drought conditions is most likely caused by the inhibition of leaf area, Relative water content and fluorescence parameters of safflower plants (Amiri et al. 2017). In their previous study, Ullah et al. (2012) investigated the effects of plant growth regulators (the SA) on different traits of canola (Brassica napus L.) and concluded that the SA was as an ineffective treatment concerning the reduction of the adverse effects of drought stress, while significantly enhanced the oil content of canola.

Increased in total saturated fatty acids and decreased in the unsaturated fatty acids under drought conditions were reported by Mona et al. (2012). A decrease in the oleic and stearic acid contents and an increase in the linoleic and palmitic acid contents have been reported by Sabagh et al. (2019) in sunflower (Helianthus annuus L.) seed oil under drought conditions. The oil composition of safflower is mainly due to its ability to accumulate phenolic and flavonoid compounds (Alizadeh-Yeloojeh et al. 2020). Treating the safflower plants by the plant growth regulators can affect the fatty acid compositions (Mona et al. 2012). The exo-application of plant growth regulators significantly enhanced the quality of oil in the safflower by improving the processes of physiological and biochemical of stress-induced plants (Sabagh et al. 2019). There is a result in the use of salicylic acid affecting the oil composition of safflower (Carthamus tinctorius L.) under drought stress (Shaki et al. 2019). The increasing oleic acid content might be attributed to the effect of the plant growth regulators on enzymes involved in fatty acid unsaturation (Ullah et al. 2012).

The safflower WUE was affected by the drought stress irrigation regimes. The amount of irrigation during the growing season and seed yield affects the WUE. Although the control regime had the maximum seed yield, the highest WUE was not observed in this regime. Based on harvested seed yield and the amount of irrigation, the severe stress was detected as the best irrigation regime in terms of the WUE. As previously mentioned, the seed yield of safflower was improved through the application of plant growth regulators, so that the highest seed yield was observed in the salicylic acid treatment. In a recent study, Tayebi et al. (2018) found that SA can preserve water content of plant cells by stimulating biosynthesis of osmolytes such as glycine betaine, soluble sugars, proline, polyphenols and polyamines. Badpa et al. (2016) showed that SA treatment increased the endogenous content of plant growth regulators in safflower stress conditions. Since the average amount of irrigation water was constant among the foliar application treatments, higher seed yield led to the greater WUE.

The current study evaluated the effects of the foliar application of the plant growth regulators on different traits of safflower under the drought stress. The results showed that the seed and oil yields of safflower were reduced when drought stress regimes were applied during the growing season due to adverse effects of drought stress on agronomic traits such as the LAI and the 1000 -seed weight. The oil quality of the safflower under drought stress conditions was decreased mainly due to the reduction in the oleic acid content. Generally, treating the safflower plant by the SA when the optimal water supply (control) was applied resulted in the best quality and quantity of the safflower oilseed.

\section{Acknowledgments}

The authors thank Dr. Christos A. Damalas (Professor Department of Agricultural Development, Democritus University of Thrace, Orestiada, Greece) for his critical reading and editing of the manuscript.

\section{References}

Ali Q, Anwar F, Ashraf M, Saari N \& Perveen R (2013). Ameliorating effects of exogenously applied proline on seed composition, seed oil quality and oil antioxidant activity of maize (Zea mays L.) under drought stress. International Journal of Molecular Science 14: 818-835 https://doi.org/10.3390/ijms14010818 
Alizadeh-Yeloojeh K h, Saeidi G h \& Sabzalian M R (2020). Drought stress improves the composition of secondary metabolites in the safflower flower at the expense of a reduction in seed yield and oil content. Industrial Crops and Products 154 (112496):1-10 https://doi.org/10.1016/j.indcrop.2020.112496

Amini H, Arzani A \& Karami M 2014. Effect of water deficiency on seed quality and physiological traits of different safflower genotypes. Turkish Journal of Biology 38(2): 271-282 https://doi.org/10.3906/biy-1308-22

Amiri A, Esmaeilzadeh Bahabadi S, Yadollahi Dehcheshmem P \& Sirousmehr A (2017). The role of salicylic acid and chitosan foliar applications under drought stress conditions on some physiological traits and oil yield of safflower (Carthamus tinctorius L.). Journal of Crop Ecophysiology (Agriculture Science) 11(41): 69-83

Azadmard-Damirchi S, Savage G P \& Dutta P C (2005). Sterol fractions in hazelnut and virgin olive oils and 4,4'-dimethylsterols as possible markers for the detection of adulteration of virgin olive oil. Journal of American Oil Chemical Society 82: 717-725 https://doi.org/10.1007/s11746-005-1133-y

Badpa K, Dehnavi M M, Yadavi A (2016). The response of safflower (Carthamus tinctorius L. cv. Soffe) seed germination under cadmium nitrate stress to salicylic acid priming. Iranian Journal of Seed Research 2 (2): 179-184

Baydar H (2002). Effects of gibberellic acid treatment for pollen sterility induction on physiological activity and endogenous hormone levels of seeds in safflower. Turkish Journal of Biology 26:235-239

Bibi M, Hussain M, Qureshi M S \& Kousar S (2003). Morpho-chemical and physiological response of sunflower (Helianthus annuus L.) to gibberellic acid and nitrogen. Pakistan Journal of Life Society Science 1: 51-53

Çamaş N \& Esendal E (2006). Estimates of broad-sense heritability for seed yield and yield components of safflower (Carthamus tinctorius L.). Hereditas 143: 55-57 https://doi.org/10.1111/j.2006.0018-0661.01914.x

Chavoushi M, Najafi F, Salimia A \& Angaji A (2019). Improvement in drought stresses tolerance of safflower during vegetative growth by exogenous application of salicylic acid and sodium nitroprusside. Industrial Crop Product 134: 168-176. https://doi.org/10.1016/j.indcrop.2019.03.071

Chavoushi M, Najafi F, Salimi A \& Angaji S A (2020). Effect of salicylic acid and sodium nitroprusside on growth parameters, photosynthetic pigments and secondary metabolites of safflower under drought stress. Scientia Horticulturae 259: 108823 https://doi.org/10.1016/j.scienta.2019.108823

Dotto L \& Neumann Silva V (2017). Beet seed priming with growth regulators. Semina: Ciencia Agrarias 38: 1785-1798 https://doi.org/10.5433/1679-0359.2017v38n4p1785

Ghassemi-Golezani K, Hosseinzadeh-Mahootchi A \& Farhangi-Abriz S (2020). Chlorophyll a fluorescence of safflower affected by salt stress and hormonal treatments. SN Applied Sciences 2: 1306 https://doi.org/10.1007/s42452-020-3133-1

Golkar P, Taghizadeh M \& Yousefian Z (2019). The effects of chitosan and salicylic acid on elicitation of secondary metabolites and antioxidant activity of safflower under in vitro salinity stress. Plant Cell, Tissue and Organ Culture 137: 575-585 https://doi.org/10.1007/s11240-019-01592-9

Golparvar A R (2011). Genetic improvement of oil yield in spring safflower cultivars under drought and non-drought stress conditions. Electronic Journal Biology 7(2): 40-43

Janmohammadi M, Amanzadeh T, Sabaghnia N \& Ion V (2016). Effect of nano-silicon foliar application on safflower growth under organic and inorganic fertilizer regimes. Botanica 22(1): 53-64 https://doi.org/10.1515/botlit-2016-0005

Jayakannan M, Bose J, Babourina O, Rengel Z \& Shabala S (2013). Salicylic acid improves salinity tolerance in Arabidopsis by restoring membrane potential and preventing salt-induced K+ loss via a GORK channel. Journal of Experimental Botany 64(8): 2255-2268 https://doi.org/10.1093/jxb/ert085

Keshavarz H \& Khodabin Gh (2019). The role of uniconazole in improving physiological and biochemical attributes of bean (Phaseolus vulgaris L.) subjected to drought stress. Journal Crop Science Biotechnology 22(2): 161-168 https://doi.org/10.1007/s12892-019-0050-0

Keshavarz H \& Sadegh Ghol Moghadam R (2017). Seed priming with cobalamin (Vitamin B 12 ) provides significant protection against salinity stress in the common bean. Rhizosphere 3: 143-149 https://doi.org/10.1016/j.rhisph.2017.04.010

Keshavarz H, Modares-Sanavy S A S \& Mahdipour Afra M (2018). Organic and chemical fertilizer affected yield and essential oil of two mint species. Journal of Essential Oil Bearing Plants 21(6): 1674-1681 https://doi.org/10.1080/0972060X.2018.1497545

Keshavarz H, Modarres Sanavy S A M \& Sadegh Gol Moghadam R (2016). Impact of foliar application with salicylic acid on biochemical characters of canola plants under cold stress conditions. Notulae Science Biology 8(1): 98-105 https://doi.org/10.15835/nsb819766

Khademian R, Ghassemi S. \& Asghari B (2019). Bio-fertilizer improves physio-biochemical characteristics and grain yield of safflower (Carthamus tinctorius L.) under drought stress. Russian Agricultural Sciences 45: 458-463 https://doi.org/10.3103/S1068367419050124

Khan A S \& Chaudhry N Y (2006). GA3 improves flower yield in some cucurbits treated with lead and mercury. African Journal of Biotechnology 5: 149-153

Lewis D C \& McFarlane J D (1986). Effect of foliar applied manganese on the growth of safflower (Carthamus tinctorious L.) and the diagnosis of manganese deficiency by plant tissue and seed analysis. Australian Journal of Agriculture Research 37: 567-572 https://doi.org/10.1071/AR9860567

Mohammadi M H, Sharifi Parastoo \& Shorafa M (2019). Comparison of the effect of cow manure, vermicompost, and azolla on safflower growth in a saline-sodic soil. Communications in Soil Science and Plant Analysis. 50(12): 1417-1424 https://doi.org/10.1080/00103624.2019.1621331

Mohammadi M, Ghassemi-Golezani K, Chaichi M R \& Safikhani S (2018). Seed oil accumulation and yield of safflower affected by water supply and harvest time. Agronomy Journal 110: 586-593 https://doi.org/10.2134/agronj2017.06.0365

Mohtashami M, Naderi A, Ghanbari A A, Alavifazel M \& Lak S h (2016). Effect of seed pre-treatment with growth regulators on seed yield and yield components of common beans (Phaseolus vulgaris L.). Turkish Journal of Field Crops 21(2): 313-317

Mona G, Dawood M, Sadak S \& Hozayen M (2012). The physiological role of salicylic acid in improving performance, yield and some biochemical aspects of sunflower plant grown under the newly reclaimed sandy soil. Australian Journal of Basic \& Applied Science 4: 8289

Moradi P, Pasari B \& Fayyaz F (2017). The effects of fulvic acid application on seed and oil yield of safflower cultivars. Journal of Central European Agriculture 18(3): 584-597 https://doi.org/10.5513/JCEA01/18.3.1933

Movahhedy-Dehnavy M, Modarres-Sanavy S A M \& Mokhtassi-Bidgoli A (2009). Foliar application of zinc and manganese improves seed yield and quality of safflower (Carthamus tinctorius L.) grown under water deficit stress. Industrial Crops and Products 30: 82-92 https://doi.org/10.1016/j.indcrop.2009.02.004 
Sabagh El, Hossain A, Barutcular C, Gormus O, Ahmad Z, Hussain S, Islam M S, Alharby H, Bamagoos A, Kumar N, Akdeniz H, Fahad S, Meena R S, Abselhamid M, WAAya A, HAAnuzzaman M, Soroir S \& Saneoka H (2019). Effects of drought stress on the quality of major oilseed crops: implications and possible mitigation strategies - a review. Applied Ecology and Environmental Research 17(2): 4019-4043 https://doi.org/10.15666/aeer/1702_40194043

SAS Institute Inc. (2002). The SAS System for Windows, Release 9.0. Statistical Analysis Systems Institute, Cary, NC, USA.

Shaki F, Ebrahimzadeh-Maboud H \& Niknam V (2019). Effects of salicylic acid on hormonal cross talk, fatty acids profile, and ions homeostasis from salt-stressed safflower. Journal of Plant Interactions 14(1):340-346 https://doi.org/10.1080/17429145.2019.1635660

Shaki F, Niknam V \& Ebrahimzadeh Maboud H (2020). Effects of penconazole on hormonal crosstalk and fatty acids from salt-stressed safflower. Iranian Journal of plant physiology 10(3): 3213-3221

Soheili-Movahhed S, Khomari S, Sheikhzadeh P \& Alizadeh B (2019). Improvement in seed quantity and quality of spring safflower through foliar application of boron and zinc under end season drought stress. Journal of Plant Nutrition. 1-12 https://doi.org/10.1080/01904167.2019.1584214

Tayebi A, Earahvash F, Mirshekari B, Tarinejad A, Yarnia M (2018). Effect of shoot application of salicylic acid on some growth parameters and yield of safflower (Carthamus tinctorius L.) under water stress. Plant Ecophysiology (Arsanjan Branch) 10 (32): 78-93

Tohidi Moghadam H R, Khamene M K \& Zahedi H (2014). Effect of humic acid foliar application on growth and quantity of corn in irrigation withholding at different growth stages. Maydica 59: 124-128

Ullah F, Bano A \& Nosheen A (2012). Effects of plant growth regulators on growth and oil quality of canola (Brassica napus L.) under drought stress. Pakistan Journal of Botany 44(6): 1873-1880

Yadollahi P, Asgharipour M R, Kheiri N \& Ghaderi A (2015). Effects of drought stress and different types of organic fertilizers on the yield and yield components of safflower (Carthamus tinctorius L.). Journal of Oil Plant Product 3(1): 27-40

Zhang L, Gao M, Zhang L, Li B, Han M, Alva A K \& Ashraf M (2013). Role of exogenous glycinebetaine and humic acid in mitigating drought stress-induced adverse effects in Malus robusta (Carrière) Rehder seedlings. Turkish Journal of Botany 37: 920-929 https://doi.org/10.3906/bot-1212-21

(c) 2021 by the authors. Licensee Ankara University, Faculty of Agriculture, Ankara, Turkey. This article is an open access article distributed under the terms and conditions of the Creative Commons Attribution (CC BY) license (http://creativecommons.org/licenses/by/4.0/). 